\title{
PINIGINĖS SOCIALINÉS PARAMOS PERTVARKA: ESMINIAI POKYČIAI IR TENDENCIJOS
}

\author{
Audrius Bitinas \\ Vilniaus universiteto Teisès fakulteto \\ Privatinès teisès katedra \\ Sauletekio al. 9, LT-10222 Vilnius, Lietuva \\ Tel. +370 68620402 \\ El. paštas: audrius.bitinas@tf.vu.lt \\ Dalius Bitaitis \\ Mykolo Romerio universiteto Socialinių technologijų fakulteto \\ Socialinio darbo katedra \\ Ateities g. 20, LT-08303 Vilnius, Lietuva \\ Tel. +370 69820929 \\ El. paštas: daliusbit@gmail.com \\ Pateikta 2014 m. liepos 3 d., parengta spausdinti 2015 m. sausio 12 d. \\ doi:10.13165/SMS-14-6-3-09 \\ Anotacija. Straipsnyje apžvelgiama socialinès paramos sistema Lietuvoje, pinigi- \\ nés socialinés paramos teikimo ypatumai, formos, analizuojama $2012 \mathrm{~m}$. piniginés so- \\ cialines paramos administravimo pertvarka, jos prielaidos ir problemos, analizuojami \\ Apibendrinant teorines išvadas, remiamasi Lietuvos Respublikos norminiu teisès \\ aktu analize, teorine medžiaga, sociologines apklausos rezultatais. Šiame straipsnyje \\ taip pat analizuojama, kaip veikia pinigines socialinès paramos sistema, analizuojami \\ pinigines socialines paramos pertvarkos motyvai ir teisine bei ekonominé argumenta- \\ cija, atliktas tyrimas, kaip vietos savivaldos darbuotojai vertina pokyčius pertvarkant \\ ISSN 2029-2244 (online) \\ http://www.mruni.eu/lt/mokslo_darbai/SMS/ \\ http://www.mruni.eu/en/mokslo_darbai/SMS/
} pinigines socialines paramos efektyvumo vertinimo kriterijai.

Socialinių mokslų studijos / Societal Studies

(c) Mykolo Romerio universitetas, 2014

(C) Mykolas Romeris University, 2014 
piniginès paramos administravima bandomosiose savivaldybèse, su kokiomis problemomis susiduria socialinès paramos teikejai po pertvarkos.

Reikšminiai žodžiai: pinigine socialinè parama, administravimas, savivaldybès, pertvarka.

\section{Ivadas}

Piniginès socialinès paramos administravimas ir efektyvumo paieška tapo aktuali po Lietuvos nepriklausomybès atkūrimo ir išliko svarbi iki šių dienų. 2008 metais prasidejusi globali ekonomikos krizė keliais kartais padidino piniginès socialinès paramos gavėjų skaičių. Socialinès apsaugos ir darbo ministerijos duomenimis, 2003 metais piniginès socialinès paramos gavėjų skaičius sudarè apie 119 tūkst., išlaidos siekè 94 mln. litų. 2007 metais ekonomikos pakilimas nulèmè, kad 2007 metais piniginès paramos gavejjų skaičius sumažèjo iki beveik 37 tūkst., o išlaidos nukrito iki $52 \mathrm{mln}$. litų. Nuo 2008 metų socialinès paramos išlaidos bei gavejų skaičius dèl ekonominio sunkmečio smarkiai išaugo ir 2011 metais buvo fiksuotos rekordinès aukštumos: 2011 metais jau 612 tūkst. asmenų gavo socialinès paramos išmokas, o lèšu poreikis sudarè $221 \mathrm{mln}$. litų.

Piniginès socialinès paramos sistema yra socialinès paramos sistemos ir gerovès sistemos integrali dalis, padedanti visuomenei spręsti iškylančias socialines problemas. Kintanti visuomenès socialinė ir ekonominè aplinka, globalizacija, viešojo sektoriaus išlaidų mažinimas, ekonominiai pokyčiai skatina ieškoti optimalių bei efektyvių socialinės paramos sistemos administravimo būdų.

1994 m. gegužès 9 d. Lietuvos Respublikos Vyriausybès nutarimu Nr. 360 patvirtintoje Socialinès paramos koncepcijoje ${ }^{1}$ numatyta, kad socialinè parama yra tobulintina, kadangi problema yra nedeklaruojamos pajamos, todèl prie remiamųjų nepagrịstai priskiriami dideles pajamas (dažnai nelegalias) gaunantys asmenys ir jų šeimos nariai; labai plati ir paini socialinès paramos pašalpų ir lengvatų sistema; socialinés paramos sistema nepakankamai veiksminga, kadangi netobulas socialinès paramos administravimas, nesusiformavusi socialinès paramos infrastruktūra, nèra socialinio darbo koncepcijos, labai stinga profesionalių socialinių darbuotojų ir socialinès paramos sistemos valdymo specialistų. Per mažai remiamasi nevalstybinėmis organizacijomis, nepakankamas dèmesys bendruomenių organizavimui (pačių žmonių galimybèms), prastai organizuotas šviečiamasis darbas, susijęs su teisingumo, solidarumo bei humanizmo idejjų skleidimu. Šioje Koncepcijoje yra aiškiai konstatuota, kad socialinė parama gyvenamojoje vietoje pranašesnè už centralizuotą, pirmenybè teikiama šeimos globai, o ne institucijų paramai. Koncepcijoje numatytas reikšmingas vietos savivaldos vaidmuo: savivaldybės atsako už socialinès paramos teikimą savo teritorijoje. Jos privalo užtikrinti ịstatymų nustatytą minimalią socialinę

1 Valstybès žinos. 1994, Nr. 36-653. 
paramą, organizuodamos privalomųjų paslaugų teikimą bei mokèdamos pašalpas, taip pat steigdamos bendruomenèse reikiamas tarnybas. Papildomą socialinę paramą savivaldybės teikia savo nuožiūra, atsižvelgdamos ị poreikius ir savo galimybes. Savivaldybių socialinės paramos tarnybų darbuotojai visų pirma rūpinasi socialinès infrastruktūros plètojimu bendruomenéje, asmenų bei privačiu organizacijų ịtraukimu ị socialinès paramos teikimą, taip pat koordinuoja jų veiklą. Savivaldybės atsako už teikiamų socialinių paslaugų kokybę.

Taigi, jau 1994 metų Koncepcijoje nurodytos reformų prielaidos nepakito iki šių dienų ir yra aktualios, siekiant piniginès socialinès paramos efektyvumo bei piniginès socialinès paramos skyrimą priartinant prie paramos gavèjo, realiai įvertinant paramos gavejo padèti.

Nuo 2012 m. sausio 1 d. pradèta piniginès socialinès paramos pertvarka: 20122013 metais piniginè socialinè parama (socialinè pašalpa ir būsto šildymo išlaidų, geriamojo ir karšto vandens išlaidų kompensacijos) teikiama igyvendinant du modelius:

- kaip valstybinè (valstybės perduota savivaldybėms) funkcija (finansuojant iš valstybès biudžeto lèšų);

- kaip savarankiškoji savivaldybių funkcija penkiose (Akmenès, Panevéžio, Radviliškio, Raseinių ir Šilalès rajonų) bandomosiose (pilotinėse) savivaldybėse (finansuojant iš savivaldybių biudžetų lèšų).

Piniginès socialinès paramos nepasiturintiems gyventojams ịstatymo projekte Nr. XIP-3743 buvo numatyta, kad bandomosiose (pilotinèse) savivaldybèse piniginès socialinès paramos teikimas (kaip savarankiškoji savivaldybių funkcija) bus vykdomas trejus metus (nuo $2012 \mathrm{~m}$. sausio $1 \mathrm{~d}$. iki $2014 \mathrm{~m}$. gruodžio $31 \mathrm{~d}$.). Taip pat šiame projekte numatyta iki $2013 \mathrm{~m}$. spalio $1 \mathrm{~d}$. j̧vertinti piniginès socialinès paramos teikimo efektyvumą (vykdant savarankiškąją savivaldybių funkciją, bandomosiose (pilotinèse) savivaldybėse) ir iki $2014 \mathrm{~m}$. kovo $1 \mathrm{~d}$. peržiūrèti teisès aktus bei parengti atitinkamų teisès aktų, susijusių su piniginès socialinès paramos teikimo vieningu teisiniu reguliavimu visose savivaldybėse, pakeitimus ar priimti naujus teisès aktus.

Priskyrus piniginès socialinès paramos teikimą savarankiškajai savivaldybių funkcijai, bandomosiose (pilotinèse) savivaldybėse piniginę socialinę paramą buvo siūloma finansuoti iš savivaldybės biudžeto lëšų. Bandomosioms (pilotinėms) savivaldybėms lèšų piniginei socialinei paramai finansuoti suma 2012-2014 metams būtų skiriama 2011 metų Valstybės biudžeto ir savivaldybių biudžetų finansinių rodiklių patvirtinimo įstatyme patvirtintos valstybès biudžeto specialiosios tikslinès dotacijos socialinems pašalpoms ir kompensacijoms skaičiuoti ir mokèti lygio.

$2011 \mathrm{~m}$. gruodžio $1 \mathrm{~d}$. buvo priimta nauja Piniginès socialinès paramos nepasiturintiems gyventojams įstatymo redakcija ${ }^{2}$. Pozityvūs reformos finansiniai rezultatai (2012 m., palyginti su $2011 \mathrm{~m}$., penkiose bandomosiose savivaldybèse 20,6 proc. vidutiniškai sumažejo išlaidos piniginei socialinei pašalpai) penkiose bandomosiose

2 Valstybès žinios. 2011, Nr. 155-7353. 
savivaldybėse sudarè prielaidas bandomąji modelị nuo 2014 metų diegti visose savivaldybėse, atitinkami įstatymo pakeitimai įsigaliojo nuo $2014 \mathrm{~m}$. sausio $1 \mathrm{~d}$.

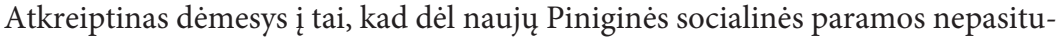
rintiems gyventojams įstatymo nuostatų (susijusių su viešųjų darbų taikymu piniginès socialinès paramos gavėjams) yra pasisakęs Panevėžio apygardos administracinis teismas. 2012 m. gruodžio 28 d. administracinèje byloje Nr. I-528-279-2012 teismas konstatavo, kad „socialinès paramos teikimo principus, finansavimo šaltinius, piniginę socialinę paramą gaunančių asmenų teises ir pareigas, taip pat piniginès socialinès paramos rūšis, jų dydžius ir teikimo sąlygas nustato 2003-07-01 Lietuvos Respublikos piniginès socialinès paramos šeimoms ir vieniems gyvenantiems asmenims ịstatymas Nr. IX-1675 bei kiti teisès aktai. İstatymo (įstatymo redakcija, galiojusi sprendimo dèl socialinès pašalpos skyrimo pareiškejui metu) 24 straipsnyje buvo ịtvirtintos piniginę paramą gaunančių asmenų pareigos, kur, be kita ko, numatyta, kad piniginę socialinę paramą gaunantys nepasiturintys gyventojai privalo dalyvauti savivaldybès administracijos organizuojamoje visuomenei naudingoje veikloje Vyriausybès ar jos igaliotos institucijos nustatyta tvarka (Itstatymo 24 str. 1 d. 5 p.). Tai imperatyvi teisès norma, kurią besąlygiškai privalu vykdyti. <...> Minėta, kad İstatymas socialinę paramą gaunantiems asmenims nustato tam tikras pareigas. Viena šių pareigų yra dalyvauti savivaldybès administracijos organizuojamoje visuomenei naudingoje veikloje Vyriausybès ar jos igaliotos institucijos nustatyta tvarka (Itstatymo 24 str. $1 \mathrm{~d}$. 5 p., galiojusi ginčui aktualiu laikotarpiu). O İstatymo 22 straipsnio 1 dalies 1 punkte (İstatymo redakcija, galiojusi ginčui aktualiu laikotarpiu) ịtvirtinta imperatyvi teisès norma, nustatanti, kad savivaldybès administracija, teikdama socialinę paramą, privalo socialinę pašalpą teikti nepinigine forma savivaldybės tarybos nustatyta tvarka $<\ldots>$ ir tais atvejais, kai bent vienas šeimos narys ar vienas gyvenantis asmuo nevykdo šio ịstatymo 24 straipsnio 1 dalies 5 punkte $<\ldots>$ nustatytų pareigų. Iš šių teisès normų nuostatų akivaizdu, jog asmuo, nedalyvaujantis savivaldybės administracijos organizuojamoje visuomenei naudingų darbų veikloje, praranda teisę gauti socialinę pašalpą pinigine forma, kadangi Itstatymas imperatyviai ịpareigoja savivaldybès administraciją socialinę pašalpą teikti nepinigine forma asmenims, nevykdantiems Istatymo 12 str. 1 d. 5 p. nustatytos pareigos.“

Tačiau, autorių nuomone, socialinès paramos sistemos efektyvumo didinimas Lietuvos savivaldybèse turi būti toliau plètojamos ne tik kiekybiniu, bet ir kokybiniu požiūriu. Taip pat, administruojant socialines paslaugas, turi būti išanalizuoti bendruomenès poreikiai ir nustatomos prioritetinès sritys. Neefektyviai administruojant socialines pašalpas, atlikta reforma gali neduoti laukiamų rezultatų ir dèl ateities ekonominès krizės vèl gali drastiškai padidèti išlaidos. Svarbu akcentuoti, kad socialinės paramos išlaidų administravimo efektyvumas negali būti vertinamas tik per finansinę prizmę, bet ir atsižvelgiant ị socialinės paramos tikslus - mažinti skurdą ir socialinę atskirtị, sušvelninti nepritekliaus pasekmes labiausiai pažeidžiamoms gyventojų grupėms bei pagerinti vaikus auginančių šeimų finansinę padètị. Apibendrinant galima pažymèti, kad piniginès socialinès paramos mokèjimo šaltinių kaita buvo tiesiogiai 
susijusi su Lietuvos Respublikos ekonomikos nuosmukiais ir pakilimais. Pirmieji metai buvo inertiškas ekonomikos palikimas nuo sovietinių laikų, po metų finansavimo šaltinių sistema plečiama, dar véliau ji pateko ị savivaldybių biudžetus. Prasidèjus bankų griūčiai Lietuvos ūkyje 1994 metais, kitų metų pradžioje išleidžiamas teisès aktas, kuris ịvardija vienintelị piniginės paramos finansavimo šaltinį - savivaldybių biudžetą. Rusijos krizè (1998-1999 m.) turëjo didelių pasekmių Lietuvos ūkiui. 2003 metais piniginès paramos šaltiniu tampa valstybės biudžetas, o po 2008-2010 metų pasaulinès ekonomikos krizės buvo vèl imtasi reformų ir socialinès paramos finansavimo šaltinių peržiūros.

Straipsnio tikslas - remiantis socialinès paramos administravimo teoriniais aspektais, problematika bei tendencijomis, aptarti piniginès socialinès paramos pertvarkos rezultatus bei administravimo efektyvumo tobulinimo kryptis, ivvertinant sociologinio tyrimo rezultatus. Šiame straipsnyje taikomi mokslinès literatūros bei teisès aktų analizės ir apibendrinimo metodai. Gauti rezultatai grupuojami bei atliekamos jų lyginamoji ir loginè analizès. Empiriniai duomenys buvo surinkti $2013 \mathrm{~m}$. spalio-lapkričio mènesiais atlikus du sociologinius tyrimus: kompleksinę respondentų (socialinès paramos organizatorių ir teikejjų) apklausą raštu tose savivaldybėse $(\mathrm{N}=62)$, kurios dalyvavo bandomajame (pilotiniame) projekte 2012-2013 metais.

\section{Piniginès socialinès paramos samprata, pertvarkos ir administravimo tobulinimas}

Socialinè parama yra viena iš sudètinių socialinès apsaugos sistemos dalių. Socialinès paramos tikslas yra padèti žmonėms, neturintiems finansinių resursų (arba jų turintiems nepakankamai). Socialinès paramos išmokos skirtos užtikrinti asmens minimalų pragyvenimo standartą ir yra finansuojamos iš valstybès biudžeto (mokesčiais). Lietuvos socialinès paramos sistemą sudaro piniginè socialinè parama ir socialinès paslaugos. Dalis piniginès socialinès paramos teikiama ịvertinant gavejų pajamas, kita dalis - tam tikroms gyventojų kategorijoms nepatikrinus jų pajamų (Guogis, Bernotas, Ūselis, 2000).

Lietuvos Respublikos konstitucijos 52 straipsnis teigia, kad valstybè laiduoja piliečiu teisę gauti senatvès ir invalidumo pensijas, socialinę paramą nedarbo, ligos, našlystès, maitintojo netekimo ir kitais ịstatymų numatytais atvejais. Taigi, piniginès socialinès paramos mokejjimas nepasiturintiems gyventojams yra valstybès prievolé, kuri negali būti paneigta arba sumažinta nesilaikant socialinio teisingumo principo.

Viena iš socialinės apsaugos sudètinių dalių yra piniginé socialinẻ parama. Lietuvos socialinès paramos sistema susideda iš dviejų sudètinių dalių: piniginès socialinès paramos ir socialinių paslaugų. Piniginès paramos tikslas yra užtikrinti gyventojams minimalų pragyvenimo standartą ir yra finansuojama iš valstybès arba savivaldybių biudžeto. Vienos piniginès paramos išmokos yra mokamos testuojant arba vertinant asmens pajamas ir turtą, kitos išmokos mokamos netikrinant asmens pajamų ir turto. Socialinių paslaugų tikslas yra sugrąžinti žmogui gebejjimus pasirūpinti savimi, 
kad galètų jaustis visaverčiu visuomenès nariu, kai žmogus to negali padaryti pats. Socialinių paslaugų teikimas yra organizuojamas pagal žmonių poreikius, paslaugos teikiamos valstybiniu, regioniniu ir instituciniu lygmeniu.

Lietuvai atkūrus Nepriklausomybę, iki 2014 metų buvo taikomi keturi piniginès paramos teikimo modeliai - pinigine parama mokama iš valstybinio socialinio draudimo fondo biudžeto; piniginè parama mokama iš valstybės biudžeto; piniginė parama mokama iš valstybès biudžeto; piniginè parama mokama iš penkių Lietuvos Respublikos savivaldybių biudžetų, kitos Lietuvos savivaldybės piniginès paramos mokejjimą vykdè iš valstybès biudžeto.

Po Nepriklausomybès atkūrimo pirmasis teisès aktas, reglamentuojantis paramos skyrimą mažas pajamas turinčioms šeimoms, buvo Lietuvos Respublikos Vyriausybès 1990 m. spalio 3 d. nutarimas Nr. 303 „Dèl socialinès pašalpos mažai aprūpintų šeimų vaikams“. Šiuo teisès aktu nustatyta, kad socialinè pašalpa 1990 metais buvo mokama iš valstybinio socialinio draudimo fondo, kuris, prireikus, papildomas iš specialiojo finansinių išteklių fondo lèšų, susidarančių plètojant komercinę prekybą ir mažmeninių kainų priedus. Šis teisès aktas galiojo tik 1990-1991 metais. 1991 metais buvo priimtas naujas dokumentas - Lietuvos Respublikos Vyriausybès 1991 m. sausio 7 d. nutarimas Nr. 6 „Dèl socialinès pašalpos mažai aprūpintų šeimų vaikams mokèjimo“, kuriame nustatyta, kad nuo $1991 \mathrm{~m}$. sausio $1 \mathrm{~d}$. piniginé socialiné parama mokama iš savivaldybių biudžeto lèšų, perduodamų i valstybinio socialinio draudimo biudžetą. İmonès, įstaigos ir organizacijos bei ūkiai socialinę pašalpą mažai aprūpintų šeimų vaikams turejo mokèti iš priskaitytų valstybiniam socialiniam draudimui lèšų, o nedirbančių asmenų (pensininkų, vienišų motinų, našlių, išsiskyrusių ir kt.) vaikams socialinę pašalpą iš savo biudžeto mokejo savivaldybès arba pagal susitarimą - valstybinio socialinio draudimo skyriai. Tokia tvarka galiojo iki $1995 \mathrm{~m}$. sausio 4 d. Lietuvos Respublikos Vyriausybès 1995 m. sausio 4 d. nutarimu Nr. 7 „Dèl socialinès pašalpos" buvo nustatyta, kad socialinę pašalpą skiria ir moka miestų (rajonų) valdybos iš savivaldybių biudžetų lěšų. Panaikinus miestų ir rajonų valdybas, Lietuvos Respublikos Vyriausybé 1996 m. liepos 5 d. nutarimu Nr. 808 „Dél Socialinès pašalpos skyrimo ir mokéjimo nuostatų patvirtinimo “ paliko tą patị pašalpos finansavimo modeli, tik pakeite pavadinimus. Pašalpas šeimoms (vienišiems asmenims) skyrẻ ir mokejo miestų (rajonų) savivaldybès iš savivaldybių biudžetų lèšų. Tokia tvarka išliko iki $2004 \mathrm{~m}$. balandžio 1. Iki šios datos Lietuvos Respublikos Vyriausybe $2000 \mathrm{~m}$. balandžio $17 \mathrm{~d}$. nutarimu Nr. 441 „Dèl socialinès pašalpos skyrimo ir mokèjimo nuostatų patvirtinimo" numatè, kad visos išlaidos, susijusios su pašalpų mokejjimu ir siuntimu, yra mokamos iš savivaldybių biudžetų lěšų.

Lietuvos Respublikos Seimas 2003 m. liepos 1 d. prièmé Lietuvos Respublikos piniginès paramos mažas pajamas gaunančioms šeimoms (vieniems gyvenantiems asmenims) ịstatymą, šis teisès aktas ịsigaliojo nuo $2004 \mathrm{~m}$. balandžio $1 \mathrm{~d}$. Remiantis šiuo ịstatymu, socialinè pašalpa ir kompensacijos mokamos iš valstybès biudžeto specialiosios dotacijos savivaldybių biudžetams. 2006 m. lapkričio 21d. Lietuvos Respublikos Seimas prièmé Lietuvos Respublikos piniginès socialinès paramos nepasi- 
turinčioms šeimoms ir vieniems gyvenantiems asmenims ịstatymą - naują redakciją, kuri ịsigaliojo nuo $2006 \mathrm{~m}$. gruodžio $1 \mathrm{~d}$. Šiame įstatyme piniginès socialinès paramos finansavimo šaltinis praplečiamas ir yra leidžiama atskirais atvejais mokèti paramą iš savivaldybès lèšų (šią tvarką tvirtina savivaldybių tarybos). Taip pat ši ịstatymo redakcija numato, jog piniginei paramai administruoti iš valstybės biudžeto specialiosios tikslinès dotacijos savivaldybių biudžetams skiriami 4 proc. socialinei pašalpai ir kompensacijoms skirtų lëšų.

Piniginès paramos finansavimo tvarkos pasikeitimų ịvyko $2011 \mathrm{~m}$. gruodžio $1 \mathrm{~d}$., kai Lietuvos Respublikos Seimas priemè naują piniginès socialinès paramos nepasiturintiems gyventojams įstatymą - naują redakciją (įsigaliojo nuo $2012 \mathrm{~m}$. sausio 1 d.). Taigi, kaip jau buvo minèta, nuo $2012 \mathrm{~m}$. iki $2013 \mathrm{~m}$. pabaigos piniginè socialinè parama teikta igyvendinant du modelius: kaip valstybinè (valstybės perduota savivaldybèms) funkcija - finansuojama iš valstybès biudžeto ir kaip savarankiška savivaldybiu funkcija penkiose (Akmenès r., Panevéžio r., Radviliškio r., Raseiniu r., Šilalès r.) savivaldybèse.

Šiuo metu galiojančio Lietuvos Respublikos piniginès socialinès paramos nepasiturintiems gyventojams ịstatymo paskirtis - nustatyti piniginès socialinès paramos teikimo principus, finansavimo šaltinius, piniginę socialinę paramą gaunančiu asmenų teises ir pareigas, taip pat piniginès socialinès paramos, teikiamos nepasiturintiems gyventojams, kai suaugę asmenys yra išnaudoję visas kitų pajamų gavimo galimybes, rūšis, jų dydžius ir teikimo sąlygas. Šis ịstatymas taikomas asmenims, kurių duomenys apie gyvenamąją vietą Lietuvos Respublikoje, o neturinčių gyvenamosios vietos - apie savivaldybę, kurios teritorijoje gyvena, yra įrašyti į Lietuvos Respublikos gyventojų registrą. İstatyme numatyta, kad socialinę pašalpą nuo 2014 metų visos savivaldybès teikia vykdydamos savarankiškąją savivaldybių funkciją, kuri yra finansuojama iš savivaldybių biudžetų lěšų.

Igyvendinant Piniginès socialinès paramos nepasiturintiems gyventojams ịstatymo nuostatas, savivaldybių veikla turi būti administruojama taip, kad būtų taikomos naujausios, pažangiausios valdymo formos, užtikrinama reikalinga bei kokybiška personalo struktūra, pakankama darbuotojų kvalifikacija, darbo krūvis, taip pat būtina siekti, kad maksimaliai būtų igyvendinti institucijos tikslai bei plètros strategija. Dabartinès viešojo administravimo tendencijos rodo, kad gerai valdomos socialinès paslaugos tada, kai plačiau dalyvauja piliečiai, vyrauja subsidiarumas, skaidrumas, atsiskaitomumas, nešališkumas, prieinamumas, bendradarbiavimas bei efektyvumas.

Lietuvos Respublikos Vyriausybės 2012 m. vasario 7 d. nutarime Nr. 171 „Dèl Viešojo valdymo tobulinimo 2012-2020 metų programos patvirtinimo" numatyta, kad ši programa parengta siekiant numatyti esminius viešojo valdymo pokyčius, kuriuos atlikti būtina, kad didètų viešojo valdymo proceso efektyvumas ir geriau būtų tenkinami visuomenès poreikiai. Viešojo valdymo procesų efektyvumą lemia viešojo valdymo institucijų ir visuomenès pastangos ir gebejimai mažiausiomis sąnaudomis priimti ir igyvendinti viešojo valdymo sprendimus, labiausiai atitinkančius visuomenès poreikius. Programoje numatyta užtikrinti konsultavimąsi su visuomene ir 
didinti jos dalyvavimo viešojo valdymo procesuose galimybes. Kad visuomenė galètų reikšti nuomonę apie teikiamų paslaugų kokybę, bus rūpinamasi, kad jos atstovai kuo aktyviau dalyvautų valdant ịstaigas, teikiančias švietimo, sveikatos, socialinės apsaugos, viešojo saugumo paslaugas, didetų šiu įstaigų tarybų vaidmuo.

Viešojo valdymo tobulinimo 2012-2020 metų programoje numatyta, kad būtina nustatyti viešųjų paslaugų kokybės standartus ir optimizuoti teikiamų paslaugų apimtị, užtikrinti nuolatinę paslaugų kokybės stebėseną ir vertinimą. Siekiant ribotais finansiniais ištekliais teikti geros kokybès paslaugas, bus optimizuojama teikiamų paslaugų apimtis, nuolat analizuojamos paslaugų teikimo procedūros, vertinamas teikiamų paslaugų tikslingumas, tiriama jų atitiktis visuomenès poreikiams. Siekiant užtikrinti visuomenès poreikius atitinkančią paslaugų kokybę tiek valstybès, tiek savivaldybių lygiu, bus nuolat vertinama paslaugų kokybè, matuojami pasitenkinimo paslaugomis rodikliai, stebima, kaip paslaugų teikèjai laikosi įsipareigojimų teikti tam tikros kokybès paslaugas, tiriami kintantys paslaugų vartotojų poreikiai ir lūkesčiai.

Kai kuriose valstybėse (Airija, Nyderlandai, Slovakija, Šveicarija, Vengrija, Vokietija) intensyviai siekiama mažinti nepasiturinčiu gyventojų ilgalaikę priklausomybę nuo piniginès socialinės paramos, skatinti integraciją ị darbo rinką ir sumažinti piktnaudžiavimo pinigine socialine parama galimybes, taikoma išmokų mažinimo schema ilgalaikiams socialinès paramos gavejams. Atsižvelgiant $\mathfrak{i}$ kitų valstybių patirtị ir siekiant tolesnių socialinès paramos efektyvumo ir tikslingumo tikslų, nuo $2013 \mathrm{~m}$. birželio $1 \mathrm{~d}$. ịsigaliojo Lietuvos Respublikos piniginès socialinès paramos nepasiturintiems gyventojams įstatymo pakeitimai, kuriais darbingo amžiaus darbingiems, bet nedirbantiems asmenims (išskyrus atvejus, kai nedirbama dèl pateisinamų priežasčiu, pvz., asmenys mokosi, yra sukakę senatvès pensijos amžių arba yra neịgalūs asmenys, arba slaugo ar prižiūri šeimos narị arba artimą giminaiț̨, kuriam reikalinga slauga ar pagalba, asmuo ne trumpiau kaip vieną mėnesi gydosi stacionarinèje asmens sveikatos priežiūros įstaigoje, yra nëščia moteris, tèvai augina vaikus iki 3 metų arba iki 8 metų, jeigu vaikas nelanko ikimokyklinio ugdymo ịstaigos dèl pateisinamų priežasčiu ir kt.), kuriems daugiau negu 12 mènesių mokama socialinè pašalpa, yra tolygiai mažinamas jos dydis, o po 60 mẻnesių visiškai nutraukiamas jos mokejjimas, jeigu asmuo nedirbo né vieno mènesio per 5 socialinès pašalpos gavimo metus, nes tuo atveju, jeigu asmuo per paskutinius 24 mėnesius dirbo 12 mėnesių, ịstatymu numatyti socialinès pašalpos gavimo laikotarpiai jiems pradedami skaičiuoti iš naujo.

Atkreiptinas demesys, kad socialinès pašalpos proporcingo mažinimo schema netaikoma vaikams, taip pat ir tuo atveju, jeigu Lietuvos teritorine darbo birža socialinès pašalpos teikimo laikotarpiu nepasiūlo asmeniui dalyvauti aktyvios darbo rinkos politikos priemonėse ar savivaldybės administracija, patikrinusi asmens gyvenimo sąlygas ir surašiusi buities ir gyvenimo sąlygų patikrinimo aktą, nusprendžia asmeniui nemažinti socialinès pašalpos dydžio. Ilgalaikiams socialinès pašalpos gavejjams yra mažinama socialinè pašalpa, tačiau valstybė skatina juos įsidarbinti, nes Piniginès socialinès paramos nepasiturintiems gyventojams ịstatymas numato, kad įsidarbinusiems socialinès pašalpos gavejjams iki 6 mènesių gali būti papildomai ski- 
riama socialine pašalpa (kurios dydis lygus 50 proc. socialinès pašalpos, mokètos per praejusius 12 mėnesių iki įsidarbinimo). Taigi asmenys, kurie yra išnaudoję visas teisètas pajamų gavimo galimybes ir atitinkantys ịstatymu nustatytus turto bei pajamų reikalavimus ir bent vieną nustatytą sąlygą, turi teisę gauti socialinę pašalpą.

Šiuo teisiniu reguliavimu siekiama stiprinti darbingo amžiaus darbingų, bet nedirbančių asmenų paskatas dirbti bei užtikrinti darbingo amžiaus asmenų motyvaciją integruotis ị darbo rinką, aktyviai ieškoti darbo bei sumažinti ilgalaikę priklausomybę nuo socialinès paramos sistemos, juolab kad ir Lietuvos Respublikos Konstitucinis Teismas savo jurisprudencijoje yra nurodęs, kad Lietuvos Respublikos Konstitucijoje įtvirtintas socialinio solidarumo principas nepaneigia atsakomybès už savo likimą, todèl socialinès apsaugos teisinis reguliavimas turi būti toks, kad būtų sudarytos prielaidos ir paskatos kiekvienam visuomenès nariui pačiam pasirūpinti savo gerove, o ne pasikliauti vien valstybès laiduojama socialine apsauga (Konstitucinio Teismo $2012 \mathrm{~m}$. vasario 6 d., $2012 \mathrm{~m}$. vasario $27 \mathrm{~d}$. nutarimai).

Taigi, apibendrinant galima pažymèti, kad norminiuose teisès aktuose, susijusiuose su socialinès paramos reguliavimu, siekiama tobulinti socialinės paramos teikimo sistemą pagal socialinio teisingumo ir veiksmingumo principus. Piniginé socialinè parama turi būti teikiama siekiant sudaryti sąlygas gauti paramą tada, kada jos labiausiai reikia, didinti motyvaciją integruotis ị darbo rinką ir išvengti skurdo spąstų bei racionaliai naudoti turimus išteklius.

\section{Piniginès socialinès paramos tikslas, principai ir rūšys}

Pinigine socialinė parama yra viena iš priemonių, kuria siekiama mažinti skurdą ir socialinę atskirț, sušvelninti nepritekliaus pasekmes labiausiai pažeidžiamoms gyventojų grupèms bei pagerinti vaikus auginančių šeimų finansinę padètị. Valstybès garantuojama piniginè socialinè parama yra nuosekliai teikiama, atsižvelgiant ị šalies socialinę ir ekonominę raidą bei valstybės finansines galimybes. Vienas pagrindinių piniginès socialinès paramos tikslų - padèti tenkinti būtiniausius poreikius tiems žmonėms, kurių gaunamos pajamos yra nepakankamos, o gebejimas pasirūpinti savimi dèl objektyvių, nuo jų nepriklausančių priežasčių, yra ribotas.

Piniginès socialinès paramos skaičiavimas ir mokejjimas priskiriamas prie valstybinių (valstybės perduotų savivaldybėms) funkcijų. Piniginè socialinè parama, išskyrus atvejus, kai socialine parama skiriama iš savivaldybès biudžeto lěšų, kredito ir palūkanų apmokejjimas finansuojami iš valstybès biudžeto specialios tikslinès dotacijos savivaldybių biudžetams.

Piniginei socialinei paramai administruoti iš valstybės biudžeto specialios tikslinès dotacijos savivaldybių biudžetams skiriami 4 proc. socialinei pašalpai ir kompensacijoms skirtų lèšų.

Socialinė pašalpa sudaro 90 proc. skirtumo tarp valstybės remiamų pajamų šeimai arba vienam gyvenančiam asmeniui ir vidutinių šeimos arba vieno gyvenančio asmens pajamų per ménesị. Nuo 2004 metų pradèta ígyvendinti vieninga pajamų ir 
turto įvertinimo principu teikiamos piniginès socialinès paramos sistema, pagal kurią parama skiriama ne tik atsižvelgiant ị šeimos pajamas, bet ir į turimą turtą.

Šiuo metu veikiančios piniginès socialinès paramos sistemą sudaro: parama, kuri skiriama nepriklausomai nuo šeimos turto ir pajamų ir nepasiturintiems gyventojams teikiama parama, skiriama ịvertinus jų turtą ir pajamas.

Estijoje ir Latvijoje veikiančios socialinès paramos sistemos iš esmès yra panašios, nes remiamos šeimos, auginančios vaikus ir, siekiant išvengti skurdo spąstų ir socialinès atskirties, skiriama parama nepasiturintiems gyventojams. Atsižvelgiant $\mathfrak{i}$ šalių finansines galimybes, dažniausiai skiriasi socialinių išmokų dydžiai, pavyzdžiui

- vienkartinè išmoka gimus vaikui: Estijoje - 320 eurų (1100 Lt), Latvijoje 296 latai (1450 Lt), o Lietuvoje - 1430 Lt.

- $\quad$ išmoka vaikui: Estijoje yra 19,18 eurų (66,4 Lt), kai auginami vienas du vaikai, o auginant tris ir daugiau vaikų, mokama 57,54 eurų (199 Lt) išmoka vaikui; Latvijoje - 8 latai (40 Lt), mokama nepriklausomai nuo auginamų vaikų skaičiaus; Lietuvoje - 97,5 Lt (kai vaikui yra 2-7 metai) arba $52 \mathrm{Lt}$ (kai vaikui yra 7-18 m., jeigu bendrai gyvenantys asmenys augina ir (ar) šeimoje globoja tris ar daugiau vaikų).

- $\quad$ socialinè pašalpa (maksimali suma, mokama vienam asmeniui): Estijoje 76,70 eurų (265 Lt), Latvijoje - 35 latai (175 Lt) (savivaldybė gali padidinti iki 90 latų (450 Lt)), Lietuvoje - 350 Lt.

Lietuvos Respublikos piniginès socialinès paramos nepasiturintiems asmenims îstatymas nustato, kad piniginè socialinè parama teikiama vadovaujantis šiais principais:

1. Bendradarbiavimo ir dalyvavimo. Piniginès socialinès paramos teikimas remiasi asmenų, kurie kreipiasi dèl piniginès socialinės paramos, bendruomenès, bendrojo naudojimo objektų valdytojų, nevyriausybinių organizacijų, savivaldybės, valstybès institucijų ir įstaigų bendradarbiavimu ir tarpusavio pagalba;

2. Prieinamumo. Piniginè socialinè parama teikiama taip, kad būtų užtikrintas piniginès socialinès paramos prieinamumas nepasiturintiems gyventojams kuo arčiau jų gyvenamosios vietos;

3. Socialinio teisingumo ir veiksmingumo. Piniginè socialiné parama teikiama siekiant sudaryti sąlygas gauti paramą tada, kada jos labiausiai reikia, didinti motyvaciją integruotis $\mathfrak{i}$ darbo rinką ir išvengti skurdo spąstų bei racionaliai naudojant turimus išteklius;

4. Visapusiškumo. Piniginė socialinè parama teikiama derinant ją su socialinèmis paslaugomis, vaiko teisių apsauga, užimtumu, sveikatos priežiūra, švietimu ir ugdymu;

5. Lygių galimybių. Piniginè socialinė parama teikiama užtikrinant nepasiturinčių gyventojų lygybę, nepaisant jų lyties, rasès, tautybės, kalbos, kilmès, socialinès

32013 m. III ketv. duomenys. 
padèties, tikèjimo, ịsitikinimų ar pažiūrų, amžiaus, lytinès orientacijos, negalios, etninès priklausomybès, religijos.

\subsection{Piniginè socialinè parama nepasiturintiems gyventojams ir išmokos mirties atveju}

Vadovaujantis Lietuvos Respublikos piniginès socialinès paramos nepasiturintiems gyventojams ịstatymu, nepasiturintiems gyventojams mokama socialiné pašalpa, garantuojanti minimalias lèšas pagrindiniams fiziologiniams poreikiams (išlaidoms maistui, drabužiams) tenkinti, ir teikiamos būsto šildymo išlaidų, išlaidų karštam bei geriamajam vandeniui kompensacijos, skirtos būsto išlaikymo išlaidoms iš dalies padengti.

Bendrai gyvenantys asmenys arba vienas asmuo turi teisę i socialinę pašalpą, jei kreipimosi metu nuosavybės teise turimo turto vertẻ neviršija turto vertės normatyvo ir pajamos yra mažesnès už valstybès remiamas pajamas (350 Lt), bendrai gyvenantiems asmenims arba vienam gyvenančiam asmeniui, kiekvienas vyresnis kaip $18 \mathrm{~m}$. bendrai gyvenantis asmuo, vienas gyvenantis asmuo arba vaikas (įvaikis) nuo $16 \mathrm{~m}$. iki $18 \mathrm{~m}$. atitinka vieną iš Piniginès socialinès paramos nepasiturintiems gyventojams ịstatyme nurodomų sąlygų. Kiekvienam kartu gyvenančiam pirmam asmeniui mokama 100 proc. dydžio socialine pašalpa, antram asmeniui -80 proc. dydžio socialiné pašalpa, trečiam ir paskesniesiems - 70 proc. dydžio socialinè pašalpa. Minimali socialinè pašalpa $50 \mathrm{Lt}$, maksimali 350 litų.

Bendrai gyvenantys asmenys arba vienas gyvenantis asmuo turi teisę gauti būsto šildymo išlaidų, išlaidų geriamajam bei išlaidų karštam vandeniui kompensaciją. Ši parama yra skiriama, jeigu būsto šildymo išlaidos (kai būsto naudingas plotas bei atskirų energijos ir kuro rūšiu sąnaudos būstui šildyti ne didesnès už nustatytus normatyvus) viršija 20 proc. skirtumo tarp bendrai gyvenančių asmenų arba vieno gyvenančio asmens pajamų ir $\mathrm{VRP}^{4}$ bendrai gyvenantiems asmenims arba asmeniui dydžio, geriamojo vandens išlaidos, kurio kiekis ne didesnis už nustatytą normatyvą, išlaidos viršija 2 proc. Bendrai gyvenančių asmenų arba asmens pajamų, karšto vandens, kurio kiekis bei atskirų energijos ar kuro rūšių sąnaudos karštam vandeniui ne didesnès už nustatytus normatyvus, išlaidos viršija 5 proc. bendrai gyvenančiu asmenų arba asmens pajamų.

4 Visos išmokos, kurios yra mokamos nuo $2014 \mathrm{~m}$. sausio $1 \mathrm{~d}$. iš savivaldybių biudžeto, turi du pagrindinius bazinius dydžius, kuriais remiantis ir yra išmokamos išmokos, tai - BSI ir VRP.

BSİ - tai bazinè socialinè išmoka, kurios dydis yra patvirtintas Lietuvos Respublikos Vyriausybès 2008 m. gruodžio 30 d. nutarimu Nr. 1366, kur nustatyta, kad nuo 2009 m. sausio 1 d. šis dydis yra 130 litų. Kitas bazinis dydis VRP - valstybès remiamos pajamos vienam asmeniui. Šis dydis yra taip pat tvirtinamas Lietuvos Respublikos Vyriausybės nutarimu ir šiuo metu yra 350 litų. BSIt - rodiklis, kurio tikslas apskaičiuoti išmokas, kurių dydị nustato teisès aktai, o VRP - rodiklis, t. y. jei žmogaus pajamos neviršija 350 litų, jis turi teisę ị valstybès piniginę paramą. 
Savivaldybės tarybos nustatyta tvarka iš savivaldybės biudžeto socialinė parama gali būti skiriama ir kitais atvejais (apmokama už skolą už bustą; kompensuojamos išlaidos už geriamąji vandenị; šildymo kompensacijos ir kt.). Vienkartinė pašalpa yra skiriama ir kitais atvejais: skurdo, benamystès, ligos, stichinès nelaimès ir kt. Pašalpos dydị ir skyrimo tvarką nustato savivaldybès tarybos.

Vadovaujantis Lietuvos Respublikos paramos mirties atveju ịstatymu, neatsižvelgiant $\mathfrak{i}$ šeimos pajamas ir turimą turtą, mirus Lietuvoje nuolat gyvenančiam asmeniui; Lietuvoje gyvenančiam užsieniečiui, kuriam leidimas laikinai gyventi išduotas kaip ketinančiam dirbti Lietuvos Respublikoje aukštos profesinès kvalifikacijos reikalaujantị darbą; Lietuvoje gyvenančiam asmeniui, įstatymų nustatyta tvarka turinčiam pabėgèlio statusą; asmeniui, kuriam taikomi Europos Sąjungos socialinès apsaugos sistemų koordinavimo reglamentai bei, gimus nurodytų asmenų negyvam vaikui, laidojančiam asmeniui išmokama 8 BSI dydžio (1040 Lt) laidojimo pašalpa.

\subsection{Išmokos vaikams}

Siekiant garantuoti socialinị saugumą vaikus auginančioms šeimoms, $2004 \mathrm{~m}$. gegužès 18 d. priimtas Lietuvos Respublikos išmokų vaikams įstatymas, kuriuo vadovaujantis vaikus auginantiems ar globojantiems asmenims iš valstybès biudžeto teikiamos šios išmokos: vienkartinė išmoka vaikui gimus ar ịvaikinus vaiką (11 BSI (1430 Lt); išmoka vaikui (0,75 BSI (97,5 Lt) ar 0,4 BSI (52 Lt)) (dydis priklauso nuo vaiko amžiaus); globos (rūpybos) išmoka (4 BSI (520 Lt)); globos (rūpybos) išmokos tikslinis priedas šeimynose globojamiems vaikams (4 BSI (520 Lt)); vienkartinè išmoka ịsikurti (75 BSI (9750 Lt)); vienkartinè išmoka néščiai moteriai (2 BSI (260 Lt)); išmoka privalomosios tarnybos kario vaikui (1,5 BSI (195 Lt).

\subsection{Socialinè parama mokiniams}

Siekiant paremti šeimas, auginančias mokyklinio amžiaus vaikus, $2006 \mathrm{~m}$. birželio 13 d. priimtas Lietuvos Respublikos socialinès paramos mokiniams įstatymas. Juo vadovaujantis mokiniams iš mažas pajamas gaunančių šeimų (pajamos vienam šeimos nariui yra $\leq 1,5$ BSI $(525 \mathrm{Lt})$ ) suteikta teisė gauti nemokamą maitinimą bei paramą mokinio reikmenims įsigyti $(156 \mathrm{Lt})$ prasidedant naujiems mokslo metams.

\section{Socialinès paramos pertvarkos bandomosiose savivaldybėse tikslai bei kokybiniai ir kiekybiniai rezultatai}

Kaip jau minėjome, jau 1994 m. gegužès 9 d. Lietuvos Respublikos Vyriausybès nutarimu Nr. 360 patvirtintoje Socialinès paramos koncepcijoje numatyta, kad socialinè parama yra tobulintina, socialinès paramos sistema nepakankamai veiksminga, netobulas socialinès paramos administravimas, socialinè parama gyvenamojoje vietoje pranašesnè už centralizuotą. Valstybès kontrole $2011 \mathrm{~m}$. gegužès 9 d. valstybinio audito ataskaitoje Nr. VA-P-10-1-5 „Socialinès paramos sistema“ taip pat pažymèjo, 
kad teisinis reglamentavimas nesudaro prielaidų valstybės biudžeto lèšas socialinei paramai naudoti efektyviau:

- nèra socialinės apsaugos išmokų rodiklių ir socialinės paramos dydžių nustatymo metodikų, todèl nèra galimybès įvertinti, ar socialinès paramos dydžiai nustatyti pagrịstai;

- $\quad$ socialinès pašalpos dydis priklauso nuo asmens (šeimos) gautų pajamų. Socialinès pašalpos dydis mažinamas ta dalimi, kokią sudaro asmens (šeimos) gautos pajamos, tačiau nèra aiškių kriterijų, kodèl vienos gautos pajamos ịskaičiuojamos, o kitos - nę̧skaičiuojamos ị asmens (šeimos) pajamas;

- socialinè parama neskatina dirbti tais atvejais, kai asmens (šeimos) gaunamų socialinès paramos išmokų (socialinès pašalpos, vaiko išmokos, socialinès paramos mokiniams) suma nežymiai mažesnè ar tokio paties dydžio kaip darbinès veiklos pajamos.

$2011 \mathrm{~m}$. gruodžio $1 \mathrm{~d}$. priimtas Piniginès paramos nepasiturintiems gyventojams įstatymas iš dalies siekia ịgvendinti esminị socialinès politikos tikslą - kad darbingi asmenys integruotųsi $\mathfrak{i}$ darbo rinką, atitinkamai apribojant paskatas gauti piniginès socialinès paramos išmokas. Taip pat finansinès paskatos geriau administruoti socialinès paramos sistemą buvo sudarytos ir savivaldybėms. Be to, buvo nuspręsta, kad lèšų suma, kuri buvo panaudota 2011 metais, bus skiriama tokia pati kaip 2011 metais trejus metus iš eilès ir lëšos, kurios liks, bus paliktos šiu savivaldybių dispozicijoje, jas savivaldybės galès naudoti savo reikmėms. Kita vertus, savivaldybėms pritrūkus lèšų, trūkumas būtų dengiamas iš savivaldybès biudžeto. Taigi, pakeitus teisinę bazę, pasikeitè piniginès paramos skyrimo bei kontrolès praktika - savivaldybės ėmė griežčiau kontroliuoti paramos gavejjus, tikrinti, ar nèra piktnaudžiaujama išmokomis.

Pertvarkos aiškinamajame rašte nurodoma, kad pagrindinis įstatymo projekto tikslas - atsižvelgiant $\mathfrak{i}$ šalies socialinius ekonominius pokyčius, tobulinti piniginès socialinès paramos teikimo sistemą, ịtvirtinant racionalesnị socialinès pašalpos teikimo ir kompensavimo už būsto šildymo, geriamojo ir karšto vandens išlaidas nepasiturintiems gyventojams principą, sustiprinti savivaldybių ir bendruomenių galias teikiant socialinę paramą, priskiriant piniginès socialinès paramos teikimą bandomosiose (pilotinèse) savivaldybèse savarankiškajai savivaldybių funkcijai bei siekiant piniginei socialinei paramai skirtų lèšų racionalesnio panaudojimo. Svarbiausi ịstatymo projekto uždaviniai:

1. Sudaryti teisinį pagrindą teikti piniginę socialinę paramą nepasiturintiems gyventojams igyvendinant du modelius: kaip valstybinę (valstybės perduotą savivaldybėms) funkciją ir kaip savarankiškąją savivaldybių funkciją bandomosiose (pilotinėse) savivaldybėse;

2. Taikyti masto ekonomijos principą, pagrịstą šeimos narių ar bendrai gyvenančių asmenų skaičiumi, skiriant piniginę socialinę paramą - socialinę pašalpą ir būsto šildymo, geriamojo ir karšo vandens išlaidų kompensacijas;

3. Ittvirtinti teisinį reguliavimą dèl papildomos socialinès pašalpos skyrimo ịsidarbinus; 
4. Supaprastinti sąlygas, kurioms esant nepasiturintys gyventojai turi teisę gauti piniginę socialinę paramą;

5. Ittvirtinti teisę ị būsto šildymo, geriamojo ir karšo vandens išlaidų kompensacijas ir būstą nuomojantiems asmenims;

6. Ittvirtinti teisinị reguliavimą dèl proporcingo socialinès pašalpos dydžio mažinimo darbingo amžiaus darbingiems, bet nedirbantiems asmenims (jų šeimoms);

7. Itvirtinti griežtesnes piniginès socialinès paramos skyrimo nuostatas asmenims, nevykdantiems İstatyme nustatytų pareigų;

8. Patikslinti asmenų, besikreipiančių dèl piniginès socialinès paramos, gaunamų pajamų ir turimo turto apskaičiavimą;

9. Išplèsti socialinès pašalpos teikimo formas bei socialinès pašalpos teikimo nepinigine forma būdus.

Prieš priimant įstatymą, visos savivaldybès buvo supažindintos su atitinkamo įstatymo projekto nuostatomis ir turejo teisę savarankiškai apsispręsti dèl piniginès socialinès paramos teikimo vykdant ją kaip savarankiškąją savivaldybių funkciją. Akmenès, Panevėžio, Radviliškio, Raseinių ir Šilalès rajonų savivaldybių administracijos, îvertinusios piniginès socialinès paramos nepasiturintiems gyventojams efektyvaus teikimo, vykdant savarankiškąją savivaldybių funkciją, galimybes, regioninius ypatumus (situaciją darbo rinkoje, paramos gavejjų skaičiaus pokyčių tendencijas, struktūrą ir pan.), finansines galimybes bei žmogiškuosius išteklius, apsisprendimą dalyvauti igyvendinant bandomąji (pilotinị) modelị pateikè raštu.

Apibendrinus ir įvertinus savivaldybių, kuriose piniginès socialinès paramos teikimas buvo priskirtas savarankiškajai savivaldybių funkcijai, praktiką ir nustačius, kad šiose savivaldybėse piniginė socialinė parama buvo teikiama veiksmingiau (taikliau ir teisingiau skiriama tiems, kam iš tiesų jos reikia, taikomos efektyvios priemonès užkertant kelią galimiems piktnaudžiavimams, paskatoms dirbti išsaugojimui, racionaliau naudojamos tam skiriamos lèšos) ir buvo priimtas sprendimas iš esmès pertvarkyti piniginès socialinès paramos nepasiturintiems gyventojams sistemą, visose savivaldybėse priskiriant piniginès socialinès paramos teikimą savarankiškajai savivaldybių funkcijai.

Taip siekiama sumažinti galimybes piktnaudžiauti pinigine socialine parama bei atsižvelgta ị $2011 \mathrm{~m}$. gegužès $9 \mathrm{~d}$. Valstybės kontrolès rekomendaciją numatyti galimybę diferencijuoti socialinès pašalpos dydi, atsižvelgiant ị tai, kiek laiko darbingo amžiaus darbingas asmuo yra registruotas darbo biržoje ir gauna socialinę pašalpą.

Kitas svarbus pertvarkos siekis - padidinti savivaldybių administracijų ir bendruomeninių organizacijų, religinių bendruomenių, religinių bendrijų, kitų nevyriausybinių organizacijų atstovų, gyvenamosios vietovès bendruomenès narių, seniūnaičių, taip pat kitų suinteresuotų asmenų bendradarbiavimą ir vaidmenį, sprendžiant piniginès socialinès paramos teikimo alternatyviomis formomis asmenims, patekusiems ị socialinę riziką, bei asmenims, nevykdantiems ịstatyme nustatytų pareigų, jos skyrimo išimties tvarka klausimus.

Šios reformos finansiniai rezultatai akivaizdūs: Socialinès apsaugos ir darbo ministerijos duomenimis, 2012 metais (palyginus su 2011 m.) penkiose bandomosiose 
(pilotinėse) savivaldybėse 14,3 proc. sumažèjo socialinès pašalpos gavejjų skaičius (nuo 18,1 tūkst. iki 15,5 tūkst. asmenų), 20,6 proc. vidutiniškai sumažèjo išlaidos socialinei pašalpai (arba 7,4 proc. sumažèjo vidutinis socialinès pašalpos dydis per mènesi vienam asmeniui). Tuo tarpu likusiose 55 savivaldybèse 0,5 proc. padidejo socialinės pašalpos gavèjų skaičius (nuo 204,6 tūkst. iki 205,7 tūkst. asmenų) ir 2 proc. vidutiniškai sumažejo išlaidos socialinei pašalpai (arba 2,5 proc. sumažèjo vidutinis socialinès pašalpos dydis per mènesị vienam asmeniui).

Vykdant pertvarką, svarbu ịvertinti ne tik kiekybinę pertvarkos išraišką (sutaupymus), bet ir siekti geresnių kokybinių rodiklių bei socialinès paramos administravimo principu igyvendinimo efektyviau administruojant išmokas. Kai kurių autorių teigimu (Petrauskiené, 2005), savivaldybių socialinių paslaugų administravimo sistemos efektyvumą nusako šie kriterijai: darbuotojų profesionalumas, vietos bendruomenès aktyvumas, tarpinstitucinis bendradarbiavimas, konkurencingumo skatinimas, geros patirties sklaida, racionalus išteklių paskirstymas. Kituose šaltiniuose galima rasti kitokią administravimo efektyvumo vertinimo klasifikaciją, apimančią strateginị planavimą, racionalų išteklių naudojimą, tarnautojų profesionalizaciją, etines normas ir vertybes, organizacijos pokyčių valdymą, tarpinstitucinį bendradarbiavimą, informacines technologijas (Česaitė E, 2005). Autorių nuomone, socialinès paramos administravimas Lietuvos savivaldybėse dabartiniu metu galètų būti vertinamas pagal tokius svarbiausius kriterijus: darbuotojų profesionalizacija; gerosios patirties siekimas; racionalus išteklių paskirstymas; informacinių technologijų taikymas ir etinių normų bei vertybių taikymas.

Bandomųjų savivaldybių darbuotojų profesionalizacijos principas buvo i̇gyvendinamas per susitikimus, kai Socialinès apsaugos ir darbo ministerijos specialistai kas ménesị vyko i̇ pilotines savivaldybes, kur susitikdavo visų penkių pilotinių savivaldybių atstovai ir buvo dalijamasi gerąja patirtimi.

Vietų bendruomenių aktyvumo kriterijus buvo igyvendinamas per piniginès paramos komisijas, ị kurių veiklą buvo ịtraukiami aktyvūs bendruomenių atstovai ir kitų valstybės institucijų atstovai. Savivaldybés prie seniūnijų sudarydavo paramos skyrimo komisijas ir jose dalyvaudavo seniūnai, seniūnaičiai, mokyklų vadovai, policijos igaliotiniai ir kiti atstovai.

Tarpinstitucinio bendradarbiavimo principas jau iš dalies buvo igyvendinamas per komisijų veiklą bei bendradarbiaujant institucijoms pačios savivaldybès teritorijoje. Siekiant efektyviai valdyti piniginès paramos finansus reikejjo glaudžiai bendradarbiauti su darbo biržų skyriais, darbo inspekcijos padaliniais, mokyklomis ir kitomis institucijomis.

Konkurencingumo skatinimas buvo galimas tik iš dalies, nes savivaldybių tarybos galejjo numatyti galimybę keisti piniginę paramą i paslaugas ir kai kuriose savivaldybèse tas buvo vykdoma.

Gerosios patirties siekimo kriterijus buvo igyvendinamas per geros praktikos sklaidos susitikimus, be to, ir savivaldybès lygmeniu: per tarpinstitucinį bendradarbiavimą bei pačių tarybų sudarytų komisijų prie seniūnijų veiklą. 
Racionalaus išteklių paskirstymo kriterijus leido savivaldybėje sutaupytas lèšas panaudoti pagal pačios tarybos numatytas tvarkas, efektyviai perskirstyti ir panaudoti turimus išteklius.

Vertinant šios pertvarkos kokybinius rezultatus, straipsnio autoriai atliko kiekybinį tyrimą - anketinę apklausą, kurios tikslas - įvertinti piniginès paramos administravimo pokyčius bandomosiose savivaldybėse ir pertvarkos efektyvumą. Iš viso buvo apklausti 62 piniginès paramos teikimo specialistai tose savivaldybèse, kurios dalyvavo pilotiniame projekte 2012-2013 metais. Tyrimo atlikimo vieta - Akmenès, Panevėžio, Radviliškio, Raseinių ir Šilalès rajonų savivaldybės. Atliekant tyrimą buvo atsižvelgiama ị tiriamųjų savanorišką sutikimą dalyvauti apklausoje. Anketinèje apklausoje dalyvavo minètų savivaldybių darbuotojai, tiesiogiai susiję su piniginès socialinès paramos administravimu.

Pagrindiniai šios savivaldybès teikiamos paslaugos (t. y. piniginès socialinès paramos administravimas) teikimo organizatoriai yra socialiniai darbuotojai, kurių darbo stažas yra daugiau kaip 10 metų (tai sudarė 48 proc. visų apklaustųjų); apklaustieji, kurių stažas sudarè iki 5 metų, sudare 25 proc.; apklaustieji, kurių stažas nuo 5 iki 10 metų, sudare 27 proc. Taigi, apklausoje dalyvavo patyrę socialiniai darbuotojai - 75 proc. visų apklaustųjų šios paslaugos organizavimo darbą dirba daugiau kaip 5 metai ir turi sukaupę nemažai darbo patirties.

Ivertinus gautus apklaustųjų (respondentų) atsakymus, galima pateikti tokias ¡žvalgas:

1. I klausimą, iš kur sužinojo apie savivaldybès priimtą sprendimą dalyvauti bandomajame piniginès paramos teikimo projekte, respondentai atsakè: iš savo tiesioginio vadovo (82 proc.), žiniasklaidos (11 procentų), artimos aplinkos (kaimynų, pažįstamų, giminaičių, draugų) - 5 proc. arba nenurodẻ šaltinio (2 proc. apklaustųjų). Manome, kad savivaldybès administracijos sprendimo priemimas nebuvo aptariamas plačiai ir buvo nepakankamai viešinamas.

2. I klausimą, ar pritaria piniginès paramos administravimo pertvarkai, 94 proc. apklaustųjų atsaké, kad pritarè, ir tik 6 proc. apklaustųjų nurodé, kad pritarè, bet abejojo sėkme. Todèl galima daryti išvadą, kad piniginès paramos teikimo administravimo pasikeitimai buvo reikalingi.

3. Atsakymai į respondentams užduotą klausimą „kas pasikeitė mano darbe prasidejus projektui?" pasiskirstè taip:

- padidejo darbo krūvis ir atlyginimas: 64 proc. atsakè „ne“, 16 proc. „taip“, 20 proc. „iš dalies“.

- padidejo darbo krūvis, bet ne atlyginimas: 73 proc. atsakè „taip“, 16 proc. „iš dalies“, 11 proc. atsake „ne“.

- pasikeitė mano teikiamų paslaugų spektras: 41 proc. atsake் „taip“, 39 proc. „iš dalies“, 20 proc. atsakè „ne“.

- atsirado lèšų paslaugų kokybei gerinti: 60 proc. atsake் „ne“, 26 proc. „iš dalies“, 14 proc. atsakè „taip“. 
- keitėsi darbo organizavimas (atsirado bendradarbiavimas su kitomis institucijomis): 51 proc. atsake „iš dalies“, 40 proc. atsakè „taip“, 9 proc. atsakè „ne“.

- darbe pasijutau svarbesnis: 56 proc. atsakè „ne“, 34 proc. „iš dalies“, 10 proc. "taip“.

- man prireikè kelti kvalifikaciją, reikèjo papildomų žinių: 63 proc. atsakè „ne“, 28 atsake „iš dalies“, 9 proc. atsake „taip“.

Apibendrinant galima daryti išvadas, jog atlygis darbuotojams už atliekamą darbą nebuvo keliamas, dauguma apklaustųjų nurodè, kad pasikeitė paslaugų spektras, taigi, galima prielaida, kad buvo pereinama nuo piniginès paramos ị kitas socialines paslaugas, paslaugų kokybei gerinti lešų atsirado labai nežymiai, išaugo bendradarbiavimas su kitomis institucijomis, mažiau negu pusẻ apklaustųjų nurodė, jog tapo svarbesni darbe ir papildomų žinių ar kvalifikacijos kèlimui poreikio didesnei daliai apklaustųjų nereikejo.

4. Kitas anketos klausimas buvo susijęs su piniginės paramos gavèjų požiūriu i piniginę paramą. Respondentų buvo klausiama, kaip pasikeitè piniginès paramos gavejų požiūris ị piniginę paramą. I šị klausimą respondentų atsakymai pasiskirste taip:

- niekas nepasikeitè: 65 proc. atsakè „iš dalies“, 30 proc. atsakè „ne“, 5 proc. atsake "taip“.

- èmèsi aktyviau ieškotis darbo: 58 proc. atsake „iš dalies“, 22 proc. atsake „taip“, 20 proc. atsake „ne“.

- patys atsisakè neteisingai gaunamos paramos: 42 proc. atsake „iš dalies“, 32 proc. atsakè „ne“, 26 proc. atsake „taip“.

- parama buvo nutraukta igaliotų institucijų: 41 proc. atsakè „iš dalies“, 37 proc. atsake „taip“, 22 proc. atsakè „ne“.

- klientai dejjo daug pastangų keisti požiūrị, bet nepavyko rasti darbo: 68 proc. atsakè „iš dalies“, 21 proc. atsake „ne“, 11 proc. atsakè „taip“.

Remiantis apklausos rezultatais, darytina išvada, kad klientų požiūris keitėsi - iš dalies didèjo paramos gavejų sąmoningumo lygis, aktyviau pradèta ieškotis darbo, tačiau esminis faktorius, dèl kurio mažèjo piniginès paramos gavejų, buvo savivaldos institucijų veiksmai.

5. Taip pat buvo siekiama išsiaiškinti, kaip savivaldybių darbuotojai įtraukiami ị sprendimų priemimą. Apklausos rezultatai parodé, kad tik 21 proc. apklaustųjų nurodé, kad dalyvavo priimant sprendimus, kaip panaudoti sutaupytas lěšas, skirtas piniginei paramai (1 pav.).

Apibendrinant galima konstatuoti, kad savivaldybių darbuotojai palankiai vertina pradètą pertvarką, tačiau jie nèra ịtraukiami ị diskusijas ar sprendimo priemimą. Pertvarka padarè poveikị socialinès paramos gavejjų elgesiui, aktyviau pradèta ieškotis darbo, tačiau esminis faktorius, dèl kurio sumažèjo piniginès paramos gavèjų, buvo savivaldos institucijų veiksmai. Kaip pozityvų rezultatą galime pabrèžti ir tai, kad išaugo bendradarbiavimo poreikis su kitomis institucijomis, nors didesnei daliai apklaustųjų nebuvo papildomų žinių ar kvalifikacijos kẻlimo poreikio. 


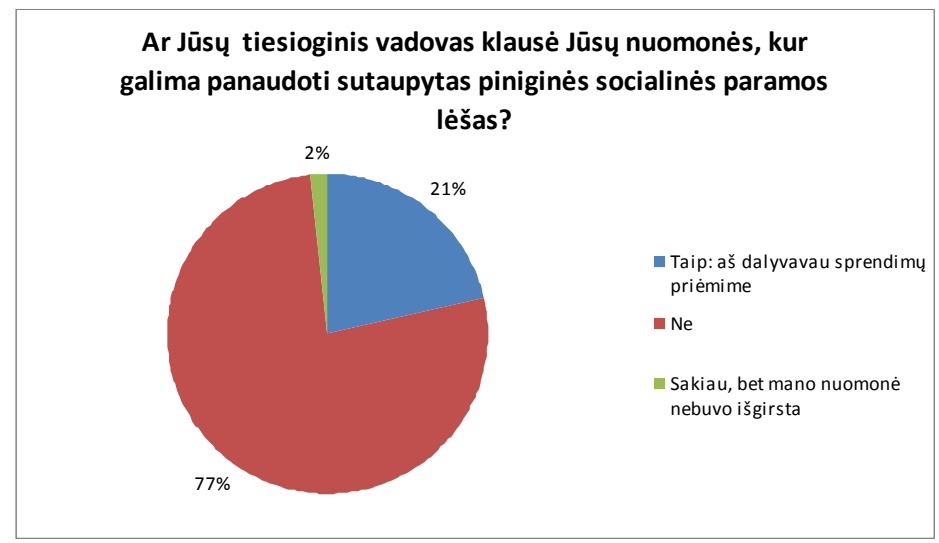

\section{Išvados}

1. Siekiant teikiamos piniginès socialinès paramos tikslingumo ir veiksmingumo bei valstybès lèšų racionalesnio panaudojimo, nuo $2012 \mathrm{~m}$. sausio $1 \mathrm{~d}$. pradèta piniginès socialinès paramos sistemos pertvarka. Pagrindinis pertvarkos tikslas - piniginę socialinę paramą nepasiturintiems gyventojams teikti igyvendinant du modelius: kaip valstybinę (valstybės perduotą savivaldybėms) funkciją ir kaip savarankiškąją savivaldybių funkciją penkiose bandomosiose savivaldybėse. Pertvarkos finansiniai rezultatai rodo, kad penkiose bandomosiose savivaldybėse 20,6 proc. vidutiniškai sumažèjo išlaidos socialinei pašalpai.

2. Norminiuose teisés aktuose, susijusiuose su socialinès paramos tobulinimu, numatoma, kad būtina tobulinti socialinès paramos teikimo sistemą, siekiant socialinio teisingumo ir veiksmingumo. Piniginè socialinė parama turi būti teikiama siekiant sudaryti sąlygas gauti paramą tada, kada jos labiausiai reikia, didinti motyvaciją integruotis ị darbo rinką ir išvengti skurdo spąstų bei racionaliai naudoti turimus išteklius.

3. Teisę ì piniginę socialinę paramą garantuoja Lietuvos Respublikos Konstitucija. Todèl negalima mažinti piniginès socialinès paramos, paneigiant socialinio teisingumo principą.

4. Piniginès socialinès paramos nepasiturintiems gyventojams teikimo sistemos pakeitimai padidins savivaldos vaidmenị, išplès jos teises ir atsakomybę už socialinès pašalpos nepasiturintiems gyventojams teikimo tikslingumą ir veiksmingumą, skatins tarpinstitucinị bendradarbiavimą, aktyvins vietos bendruomenes, sudarys sąlygas efektyviau ir socialiai teisingiau teikti socialinę pašalpą, taip pat spręs socialinès pašalpos finansavimo problemas, užtikrins socialinį teisingumą bei efektyvų ir racionalų finansinių išteklių panaudojimą. 
5. Būtina rengti kvalifikacijos kèlimo kursus darbuotojams, taip didinant jų profesionalumą.

6. Savivaldybių darbuotojai palankiai vertina pradėtą pertvarką, tačiau jie nėra įtraukiami ị diskusijas ar sprendimo priemimą. Savivaldybės administracijos sprendimo prièmimas nebuvo aptariamas ir buvo nepakankamai viešinamas savivaldybių viduje.

7. Piniginès socialinès paramos pertvarka padarè poveikị socialinès paramos gavèjų elgesiui, aktyviau pradèta ieškotis darbo, tačiau esminis piniginès paramos gavejjų mažejimo faktorius buvo savivaldos institucijų veiksmai.

8. Kaip pozityvų rezultatą galime pabréžti ir tai, kad išaugo bendradarbiavimo poreikis su kitomis institucijomis, nors papildomų žinių ar kvalifikacijos kèlimo poreikio didesnei daliai apklaustųjų nebuvo.

9. Socialinès paramos sistemos efektyvumo didinimas Lietuvos savivaldybėse turi būti toliau plètojamos ne tik kiekybiniu, bet ir kokybiniu požiūriu. Taip pat, administruojant socialines paslaugas, turi būti išanalizuoti bendruomenès poreikiai ir nustatomos prioritetinès sritys. Neefektyviai administruojant socialines pašalpas, atlikta reforma gali neduoti laukiamų rezultatų ir dèl ateities ekonominès krizès vèl gali drastiškai didèti išlaidos.

10. Socialinès paramos išlaidų administravimo efektyvumas negali būti vertinamas tik per finansinę prizmę, bet ir atsižvelgiant ị socialinès paramos tikslus - mažinti skurdą ir socialinę atskirtị, sušvelninti nepritekliaus pasekmes labiausiai pažeidžiamoms gyventojų grupèms bei pagerinti vaikus auginančių šeimų finansinę padètị.

\section{Literatūra}

Česaitè, E. Viešųư instituciju veiklos efektyvumo vertinimo elementai [interaktyvus]. [žiūrèta 2008-12-01].<http:// www.lzuu.lt/jaunasis_mokslininkas/ smk_2005/Kaimo\%20pletra/Cesaite\%20Erika.htm.>.

Guogis, A. Socialinès politikos modeliai. Vilnius: Eugrimas, 2000.

Guogis, A.; Bernotas, D.; Ūselis, D. Lietuvos politiniu partiju samprata apie socialine apsauga. Vilnius: Eugrimas, 2000.

Lietuvos Respublikos Konstitucija. Valstybes žinios. 1992, Nr. 33-1014.

Lietuvos Respublikos Konstitucinio Teismo 2012 m. vasario 6 d. nutarimas „Dèl pensijų perskaičiavimo ir mokejjimo valstybeje susidarius itin sunkiai eko- nominei, finansinei paděčiai“. Valstybés žinios. 2012, Nr. 109-5528.

Lietuvos Respublikos Konstitucinio Teismo $2012 \mathrm{~m}$. vasario $27 \mathrm{~d}$. nutarimas „Dèl motinystés, tévystés, motinystès (tévystès) pašalpų skyrimo ir mokejimo ribojimo, taip pat dèl muitinès pareigūnų teisès dirbti kitą darbą ribojimo". Valstybès žinios. 2012, Nr. 26-1200.

Lietuvos Respublikos paramos mirties atveju ịstatymas. Valstybés žinios. 1993, Nr. 73-1371.

Lietuvos Respublikos išmokų vaikams isstatymas. Valstybès žinios. 1994, Nr. 89-1706.

Lietuvos Respublikos socialinès paramos mokiniams ịstatymas. Valstybès žinios. 1996, Nr. 73-2755. 
Naujoji viešoji vadyba (ats. red. A. Raipa). Kaunas: Technologija, 2007.

Piniginès socialinès paramos nepasiturintiems gyventojams istatymo projektas Nr. XIP-3743.

1994 m. gegužès 9 d. Lietuvos Respublikos Vyriausybės nutarimas Nr. 360 „Dèl Socialinès paramos koncepcijos patvirtinimo“. Valstybès žinios. 1994, Nr. 36-653.

Lietuvos Respublikos Vyriausybès $2012 \mathrm{~m}$. vasario $7 \mathrm{~d}$. nutarimas Nr. 171 „Dèl Viešojo valdymo tobulinimo 2012-2020 metu programos patvirtinimo“. Valstybés žinios. 2012, Nr. 22-1009.

Panevėžio apygardos administracinio teismo 2012 m. gruodžio $28 \mathrm{~d}$. administracineje byloje Nr. I-528-279-2012.
Petrauskienè, R. Lietuvos vietos savivaldybiu vidaus administravimo tobulinimo kryptys. Viešoji politika ir administravimas. 2005, 9.

Piniginès socialinès paramos nepasiturintiems gyventojams istatymas. Valstybès žinios. 2003, Nr. 73-3352; 2011, Nr. 155-7353.

Valstybès kontrolès $2011 \mathrm{~m}$. gegužès $9 \mathrm{~d}$. valstybinio audito ataskaita Nr. VA-P10-1-5 „Socialinès paramos sistema“ [interaktyvus]. [žiūrèta 2014-02-11]. <http://www.vkontrole.lt/audito_ataskaitos.aspx?tipas $=2>$.

Žalimienè, L. Socialinès paslaugos. Vilnius: VU specialiosios psichologijos laboratorija, 2003.

\title{
THE SOCIAL ASSISTANCE IN CASH REFORM: THE FUNDAMENTAL CHANGES AND TRENDS
}

\author{
Audrius Bitinas \\ Mykolas Romeris University, Lithuania \\ Dalius Bitaitis \\ Mykolas Romeris University
}

Summary. The article overviews the features and framework of monetary social care system in Lithuania. The monetary social care administrative reforms that took part in 2012 are thoroughly analysed, taking into account the problems that led to changes and efficiency criteria set-up to evaluate the aftermath of the reform.

The theoretical conclusions are based on the Republic of Lithuania legal acts, theoretical material and a sociological survey. The article also examines how the monetary system works, what are the motives for monetary social system change from a legal and economic perspective. The study was carried on in order to find out how the local authority employees evaluated changes in the monetary social care administrative system and what challenges they had to face after the reform. Social workers were questioned from municipalities that decided to take part in the pilot program.

Monetary social care system is a social support system and at the same time the most integral part of the welfare system, helping to resolve social problems that arise. 
The changing social and economic environment, globalization, public sector spending cuts, economic change encourage to search for optimal and effective social support system management methods.

On the 1st of January 2012, monetary social care system change was initiated: 2012-2014 monetary social benefits (social allowance, heating cost, drinking water, and hot water cost compensations) were implemented using two models:

- State wise (state delegates to municipalities) function (financed from the government budget);

- Individualised function in five (Akmenè, Panevežys, Radviliškis, Raseiniai and Šilale regions) experimental (pilot) municipalities (financed from the municipality funds).

However, the authors of the article believe that social care system effectiveness has to be further increased, not only increasing the number of decision making municipalities, but also pushing the quality of the reform upwards. Moreover, the administration of social care benefits has to cover up society's needs and priorities. Ineffective administration of social services may result in unfavourable results and future recessions can lead to increased costs for social services. Social care administrative effectiveness cannot be evaluated only from the financial side, social goals have to be considered, too, such as decreasing poverty, tackling social exclusion, lowering the effects of poverty traps for most vulnerable groups of people and helping families with children.

Keywords: social assistance in-cash, administration, municipalities, reform.

Audrius Bitinas, Vilniaus universiteto Privatinès teisès katedros docentas. Mokslinių tyrimų kryptys: socialinès apsaugos ir darbo teisè, Europos Sąjungos socialinė politika, pensijų sistemų reformos.

Audrius Bitinas, Mykolas Romeris University, Business Law Department, Professor. Research interests: social protection and labour law, European Union social policy, pension system reforms.

Dalius Bitaitis, Mykolo Romerio universiteto Socialinio darbo katedros lektorius. Mokslinių tyrimų kryptys: socialinės paramos sistema, jos reformos.

Dalius Bitaitis, Mykolas Romeris University, Social Work Department, lecturer. Research interests: social assistance system and reforms. 